Jurnal Penelitian dan Pengabdian Kepada Masyarakat Bidang ilmu Pendidikan

\title{
Konstruksi Pluralisme Agama dalam Praktik Pembelajaran Pendidikan Agama Islam di SMA Negeri 1 Dompu
}

\author{
Ilyas Yasin \\ Dosen Program Studi Pendidikan Sejarah, STKIP Yapis Dompu \\ E-mail: ilyasdompu73@yahoo.co.id
}

Article History: Received: 2020-09-14 || Revised: 2020-11-02 || Published: 2021-01-25

Sejarah Artikel : Diterima: 2020-09-14 || Direvisi: 2020-11-02 || Dipublikasi: 2021-01-25

\begin{abstract}
As an educational institution, the school is basically a "microcosm" which should reflect reality and plurality, including religious pluralism, which exist in society. This study aims to want to see how teachers understand and interpret Islamic religious pluralism in Islamic learning. This study used a qualitative approach to data collection techniques through observation, interviews and document study. The results of this study indicate that the practice of teaching religious education is precisely to strengthen their own religious truth claims. Although status as a public school, the reality of Islamic Education (PAI) in SMAN 1 Dompu still strongly influenced by the spirit of truth claims. Consequently, religious tolerance became one of the learning objectives PAI difficult to materialize. Conversely, religious education reinforces segregation antarpemeluk religion. Therefore, the future orientation of Islamic learning must be directed at efforts to cultivate moral concern with the problems of humanity.
\end{abstract}

Keywords: Religion, Pluralism, Claims-righteousness, moral concern.

\begin{abstract}
Abstrak
Sebagai lembaga pendidikan, sekolah pada dasarnya merupakan "mikrokosmos" yang harus merefleksikan realitas dan pluralitas, termasuk pluralitas agama, yang ada dalam masyarakatnya. Penelitian ini bertujuan hendak melihat bagaimana guru PAI memahami dan memaknai pluralisme agama dalam pembelajaran PAI. Penelitian ini menggunakan pendekatan kualitatif dengan teknik pengumpulan data melalui observasi, wawancara dan studi dokumen. Hasil penelitian ini menunjukkan bahwa praktik pembelajaran pendidikan agama justeru memperkokoh klaim kebenaran agama sendiri. Meski berstatus sebagai sekolah umum, kenyataannya Pendidikan Agama Islam (PAI) di SMAN 1 Dompu masih sangat kuat dipengaruhi semangat truth claim. Akibatnya, toleransi beragama yang menjadi salah satu tujuan pembelajaran PAI sulit terwujud. Sebaliknya, pendidikan agama makin memperkokoh segregasi antarpemeluk agama. Oleh karena itu, ke depan orientasi pembelajaran PAI harus diarahkan pada upaya untuk menumbuhkan kepedulian moral bersama pada masalah-masalah kemanusiaan universal.
\end{abstract}

Kata kunci: Agama, Pluralisme, Klaim-kebenaran, Kepedulian-moral.

\section{PENDAHULUAN}

Sejak tahun 1996 pluralitas kehidupan sosial keagamaan di Tanah Air menghadapi ujian yang bertubi-tubi. Sejumlah kekerasan etnik dan konflik bernuansa agama terjadi dalam skala massif seperti kasus Sambas, Banyuwangi, Situbondo, Poso, Ambon, pengeboman gereja pada malam Natal dan Tahun Baru, Bom Bali, kekerasan terhadap Ahmadiyah (Parung, Lombok dan Kuningan) hingga sengketa pendirian rumah ibadah dan tindak kekerasan di Kabupaten Bekasi. Dalam Laporan Tahunan tentang Kehidupan Beragama yang dirilis CRCS-UGM (2010) disebutkan bahwa selama tahun 2009 terdapat 18 kasus kekerasan berkaitan dengan rumah ibadah, 25 kasus penodaan agama, dan 11 kasus berkaitan dengan kelompok Ahmadiyah. Kasus-kasus ini menunjukkan bahwa masih terdapat masalah besar dalam kerukunan hidup beragama di Indonesia. Kendati di Indonesia dialog antarumat beragama telah dilakukan sejak 1969, namun daftar panjang kekerasan berlatar agama di atas membuktikan bahwa pluralitas keagamaan merupakan masalah yang bersifat laten. Meski "agama" bukanlah faktor tunggal, namun digunakannya (baca: diperalat) sentimen agama 
dalam konflik-konflik di atas menunjukkan rapuhnya kohesi sosial dalam masyarakat sehingga simbol-simbol agama mudah dimanipulasi.

Sekolah merupakan salah satu elemen penting yang memengaruhi corak kehidupan masyarakat (Jalal dan Musthafa, 2001). Sebagai lembaga resmi, sekolah memainkan peranan dalam melakukan rekayasa formal terhadap cara berpikir peserta didik dan anggota masyarakat. Sekolah---di samping lingkungan, pola asuh dan interaksi sosial---menjadi instrumen efektif bagi pembentukan konstruksi pandangan-dunia (world-view) seseorang dalam mendefinisikan dan menginterpretasikan realitas di sekitarnya. Dilihat dari perspektif ini maka sekolah seharusnya menjadi "mikrokosmos" yang merefleksikan situasi dan kondisi yang hidup dan berkembang dalam masyarakatnya, sehingga aktivitas dan praktik pembelajaran di sekolah juga harus mencerminkan realitas yang ada dalam masyarakat. Dalam konteks pluralitas keagamaan, ini berarti bahwa sekolah bertanggungjawab menyiapkan peserta didik untuk menjawab tantangan masa depan, termasuk hidup dalam realitas kemajemukan beragama. Melihat fungsi strategis sekolah tersebut maka jelas sekolah---atau pendidikan umumnya---merupakan kunci bagi eksistensi, kelangsungan, dan keamanan global (Olsen dkk dalam Tilaar dan Nugroho, 2008: 267). Hal itu disebabkan oleh corak kehidupan global yang kian bersifat interdependen dan berkoeksistensi sehingga menuntut adanya saling pengertian, saling percaya dan kerjasama antarwarga agar dapat hidup bersama (to life together). Di sisi lain, pendidikan agama yang diajarkan di sekolah---dan menjadi mata pelajaran wajib pada semua jenjang, jenis dan jalur pendidikan nasional---dapat menjadi penghalang tumbuhnya suasana saling pengertian tersebut di kalangan siswa. Pada jalur pendidikan umum seperti Sekolah Menengah Atas (SMA), pendidikan agama Islam bagi siswa muslim, misalnya, termuat dalam mata pelajaran Pendidikan Agama Islam (PAI).

Sebagai sebuah doktrin keagamaan, materi PAI selain diproyeksikan untuk meningkatkan pemahaman dan pengamalan ajaran Islam juga untuk memperkuat dasar-dasar dan sistem keyakinan (belief system), termasuk menanamkan klaim kebenaran (truth claim) mutlak terhadap agama yang dianut siswa. Dengan demikian, praktik pembelajaran PAI di sekolah dapat mengarahkan dan membentuk siswa pada sikap dan perilaku eksklusif. Sedangkan di sisi lain, sebagai obyek pembelajaran siswa juga harus membangun interaksi sosialnya dengan lingkungan yang plural, termasuk dengan agama-agama yang berbeda. Di sini, tuntutan antara pluralitas keagamaan di satu sisi dengan klaim-kebenaran di sisi lain seringkali melahirkan ketegangan baik yang bersifat doktrinal, psikologis maupun sosial.

Berdasarkan kenyataan tersebut maka menarik untuk melihat bagaimana peran sekolah dalam mendorong dan mengembangkan sikap keberagamaan siswa dalam merespon realitas kemajemukan keagamaan di masyarakat. Sebagai salah satu agen sosial cukup penting, produksi dan reproduksi nilai-nilai keagamaan yang dipelajari di sekolah akan ikut memengaruhi raw input sekolah yakni siswa. Dalam hal ini praktik pembelajaran yang dilakukan guru PAI di sekolah ikut memengaruhi cara pandang siswa dalam memahami dan memaknai nilai-nilai pluralitas keagamaan di lingkungannya. Dalam konteks praktik pembelajaran PAI di SMAN 1 Kabupaten Dompu, secara spesifik realitas tersebut menarik diteliti terutama dalam kaitannya dengan posisi Islam sebagai agama mayoritas (siswa) berhadapan dengan agama-agama lain seperti Kristen, Hindu, dan Budha.

Bertolak dari permasalahan tersebut di atas maka fokus penelitian ini adalah bagaimana konstruksi pluralisme agama dalam praktik pembelajaran PAI di SMAN 1 Dompu. Sedangkan tujuan penelitian ini adalah untuk mendeskripsikan makna pluralisme agama menurut persepsi guru PAI. Penelitian ini dapat menjadi masukan dalam penyusunan kebijakan pendidikan agama maupun perbaikan praktik pembelajaran PAI di sekolah.

\section{METODE PENELITIAN}

Penelitian ini menggunakan pendekatan kualitatif yang menekankan kedalaman dan kealamian dari subjek yang diteliti (natural setting) sebagai sumber data langsung. Pengumpulan data dilakukan dengan menggunakan teknik observasi partisipatif, wawancara mendalam, dan studi dokumentasi. Analisis data dilakukan sejak memulai maupun setelah kegiatan penelitian. Data primer penelitian ini adalah guru PAI yang mengajarkan materi berkaitan pluralisme agama. Berhubung materi tersebut hanya dipelajari di kelas XII maka subjek yang diteliti dalam penelitian ini difokuskan hanya pada satu guru yang mengajar pada kelas tersebut. Pemilihan satu guru PAI 
tersebut sesuai dengan corak pendekatan penelitian kualitatif yang menggunakan sample purposive yakni guru yang dianggap memiliki pengetahuan yang mendalam dan mewakili informan yang ada.

\section{HASIL DAN PEMBAHASAN}

\section{A. Hasil Penelitian}

Dalam Peraturan Menteri Pendidikan Nasional (Permendiknas) No. 22 Tahun 2006 tentang Standar Isi Mata Pelajaran PAI untuk Sekolah Menengah Atas dijelaskan bahwa materi PAI mencakup lima aspek yaitu Al-Quran, Akidah, Akhlak, Fikih, dan Tarikh dan Kebudayaan Islam. Bila dicermati, berdasarkan ketentuan ini materi tentang pluralisme agama diajarkan pada kelas XII pada dua tempat pembahasan yang berbeda. Pertama, diajarkan pada semester ganjil yang diintegrasikan dalam aspek Al-Quran dengan Standar Kompetensi (SK) yang diharapkan adalah siswa memahami ayat-ayat Al-Quran tentang anjuran bertoleransi. Sedangkan Kompetensi Dasar (KD) yang hendak dicapai adalah disamping siswa dapat menerjemahkan dan membaca ayat-ayat yang berkaitan dengan toleransi sesuai hukum bacaan yang benar (ilmu tajwid) juga membiasakan perilaku bertoleransi sebagaimana terkandung dalam ayat-ayat tersebut.

Kedua, diajarkan pada semester genap dan dimasukkan dalam aspek Akhlaq. Standar Kompetensinya adalah membiasakan perilaku terpuji, sementara Kompetensi Dasarnya siswa memiliki pengetahuan tentang persatuan dan kerukunan serta menampilkan dan membiasakan perilaku persatuan dan kerukunan. Kendati dikelompokkan dalam dua aspek maupun pokok bahasan yang berbeda, namun substansi pembahasan keduanya relatif sama yakni menjelaskan bagaimana sikap seorang muslim dalam menyikapi perbedaan agama yang ada. Pembahasan kedua topik tersebut juga sama-sama menggunakan istilah 'toleransi' atau 'kerukunan' beragama, bukan 'pluralisme' agama. Sesuai standar dan acuan nasional, praktik pembelajaran di sekolah menengah terdiri atas tiga tahap yaitu kegiatan awal, kegiatan inti, dan kegiatan penutup. Dalam Rencana Pelaksanaan Pembelajaran (RPP) yang disusun guru PAI SMA 1 Dompu ditemukan bahwa tahap dan praktik pembelajaran tentang toleransi beragama dilakukan sebagai berikut. Pada kegiatan awal, setelah memberi salam dan membuka pembelajaran guru mengajak siswa membaca Al-Quran secara bersama-sama selama 5-10 menit dan menjelaskan secara singkat tentang materi yang akan diajarkan serta kompetensi dasar yang akan dicapai. Pada kegiatan inti, guru dan siswa melakukan sejumlah kegiatan yang terbagi dalam tiga bagian yaitu ekspolarasi, konsolidasi pembelajaran, dan pembentukan sikap dan perilaku (to be).

Kegiatan eksplorasi adalah semacam tes awal (pre test) dan appersepsi sebelum kegiatan pembelajaran dilakukan. Eksplorasi dimaksudkan untuk mengetahui penguasaan peserta didik terhadap materi yang akan dipelajari. Dalam bagian ini guru mengajukan beberapa pertanyaan pancingan atau dasar kepada siswa. Jawaban-jawaban yang relevan dari siswa ditulis oleh guru di papan tulis dan dikomentari secara singkat. Setelah itu, di bawah bimbingan guru, dilakukan pembacaan ayat-ayat Al-Quran secara klasikal yang dipimpin seorang siswa. Beberapa bagian ayat Al-Quran berkaitan dengan toleransi yang dibahas pada pokok bahasan ini adalah Surat Al-Kafirun ayat 1-6, Surat Yunus ayat 40-41, dan Surat Al-Kahfi ayat 29. Setelah selesai membaca Al-Quran secara klasikal, guru meminta beberapa siswa untuk membacakan ayat-ayat yang berkaitan dengan toleransi tersebut serta menjelaskan hukum bacaannya. Selanjutnya pada kegiatan konsolidasi pembelajaran, guru meminta siswa untuk membacakan terjemah ketiga surat di atas dan mengajukan beberapa pertanyaan tentang arti kosa kata dari dari ayat-ayat yang dibaca. Setelah itu guru menerjemahkan beberapa kosa kata dan meminta siswa menulis dan menerjemahkan secara lengkap ayat-ayat dimaksud. Guru juga menjelaskan hukum-hukum bacaan dan hikmah yang terkandung dalam ayat-ayat tentang toleransi. Selanjutnya, guru menugaskan siswa untuk berdiskusi secara kelompok dan menyampaikan hasilnya tentang contoh perilaku-perilaku toleransi. Pada kegiatan Pembentukan Sikap dan Perilaku, guru menjelaskan tentang nilai-nilai, sikap, dan perilaku utama yang terdapat dalam ketiga surat tentang toleransi tersebut seperti sikap toleransi, kebebasan beragama, dan tidak memaksakan ajaran agama kepada orang lain.

Pada kegiatan akhir, sebelum menutup kegiatan pembelajaran guru meminta tiap siswa untuk membaca kembali ketiga surat yang berkaitan dengan toleransi beragama di atas. Guru juga meminta siswa untuk mempelajari kembali arti, hikmah, dan kandungan ayat-ayat toleransi. Menjelang berakhirnya kegiatan pembelajaran, guru melakukan penilaian dengan menggunakan beberapa pilihan atau teknik tes yaitu tes perbuatan (performance) dan tes tertulis. Kedua tes 
tersebut dimaksudkan untuk mengetahui penguasaan siswa terhadap materi pembelajaran maupun praktik toleransi yang dilakukannya. Dalam penjelasannya tentang makna 'toleransi' guru menyatakan bahwa toleransi adalah sikap menghormati dan menghargai keyakinan dan agama lain yang berbeda dengan keyakinan dan agama sendiri. Sementara tujuan toleransi adalah agar tercipta kerukunan kehidupan beragama dan sebaliknya terhindar dari sikap salah paham antarumat beragama.

Bila dicermati, makna 'toleransi' seperti dikemukakan guru di atas merupakan pengertian yang paling umum tentang toleransi yang dipahami masyarakat luas selama ini. Pengertian semacam ini secara implisit cenderung pasif dan defensif sesuai makna kata toleransi itu sendiri. Dalam Kamus Umum Bahasa Indonesia (1984: 1084) 'toleransi' berarti "sifat atau sikap menenggang (menghargai, membiarkan, membolehkan) pendirian (pendapat, pandangan, kepercayaan, kebiasaan, kelakuan dsb) yang lain atau bertentangan dengan pendiriannya sendiri, misalnya toleransi agama, ideologi, ras dll". Demikian juga halnya dengan istilah 'kerukunan' yang mengandung arti "baik dan damai" atau "bersatu hati". Akan tetapi, dalam konteks perbedaan agama, bagaimana cara untuk mencapai dan mewujudkan sikap menghormati perbedaan tersebut tidak dapat dijelaskan oleh istilah 'toleransi' dan 'kerukunan' tersebut. Dengan kata lain, kedua istilah tersebut lebih mengacu pada "sikap menghormati tanpa dilandasi pengetahuan dan pemahaman" terhadap sesuatu yang dihormati tersebut. Pokok bahasan tentang toleransi beragama hanya diarahkan kepada penanaman sikap "agar tidak terjadi ketegangan dan permusuhan" (Nasution, 2000: 57); dan belum diarahkan pada upaya untuk memahami perbedaan agama secara mendalam. Dalam jangka panjang, sikap seperti ini cukup rentan terhadap timbulnya kesalahpahaman antara pihak-pihak yang saling berhubungan tersebut.

Hal tersebut berbeda dengan istilah 'pluralisme' agama yang mengharuskan adanya sikap proaktif. Dalam perspektif pluralisme, perbedaan-perbedaan agama tidak sekedar dihargai dan dihormati tapi juga untuk dipelajari bahkan---kalau mungkin---dihayati. Mengacu pada konsep ten commandment yang dikemukakan Swidler (1984), dorongan untuk mempelajari dan menghayati agama orang lain hanya mampu tumbuh jika yang bersangkutan menempatkan dan memperlakukan agama yang berbeda tersebut dalam posisi setara dengan agama yang dianutnya. Dengan demikian, sikap menghormati perbedaan tersebut bukan sekedar untuk keperluan etika dan basa-basi sosial melainkan penganut agama lain dapat mengambil manfaat dari perbedaan agama tersebut. Hal itu, jika menggunakan kerangka Perenial (Nasr 1993; Schoun 1994), bertolak dari keyakinan bahwa terdapat kebenaran universal dalam setiap jantung agama.

Selain cenderung pasif dan defensif, pada saat yang sama makna toleransi secara implisit juga mengandung klaim kebenaran (truth claim) terhadap agama sendiri dan sebaliknya menganggap 'sesat' agama dan keyakinan yang lain. Sikap 'membiarkan' dalam makna toleransi mengandung pengertian bahwa sikap tersebut dipilih atau dilakukan karena berdasarkan keyakinan bahwa apa yang dilakukan oleh penganut agama yang berbeda itu (baik keyakinan, ibadah, maupun sistem sosial yang dibentuk oleh agama bersangkutan) merupakan bentuk penyimpangan. Karena itu pula dalam doktrin agama-agama tertentu, khususnya agama misi seperti Islam dan Kristen, dorongan untuk menyelamatkan 'kesesatan' semacam itu dipandang sebagai sebuah kebaikan. Itulah sebabnya sistem pendidikan dan pembelajaran pendidikan agama dengan semangat klaim kebenaran serta tugas penyelamatan seperti di atas masih berlangsung hingga kini. Sementara praktik pembelajaran agama yang responsif dan akomodatif terhadap agama yang berbeda sejauh ini belum banyak dilakukan. Hal itu dengan mudah dapat dilihat dari penjelasan atau uraian dalam beberapa buku teks PAI di SMA.

Sementara itu, ketika menjelaskan tentang batas-batas toleransi beragama guru menegaskan bahwa toleransi hanya boleh dilakukan dalam urusan sosial kemasyarakatan dan tidak boleh dalam urusan keyakinan dan peribadatan. Mengambil contoh tentang toleransi dalam kehidupan sosial, guru menyebutkan antara lain belajar bersama, jual beli, gotong royong, bergaul, bertetangga dan lain-lain. Sedangkan toleransi dalam hal ibadah guru menyontohkan:

Jika kamu merayakan hari Lebaran nggak perlu mengajak temanmu yang nonmuslim untuk ikut merayakannya. Demikian pula, jika ada temanmu yang Galungan (hari raya umat Hindu, red.), kamu juga nggak perlu ikut. Kamu juga dilarang memakan hewan sembelihan serta menikah dengan nonmuslim. 
Menanggapi pertanyaan seorang siswa tentang kebolehan pria muslim menikah dengan perempuan nonmuslim khususnya dari penganut ahlul kitab, guru memberi jawaban sebagai berikut:

Meski Islam membolehkan seorang pria muslim menikahi wanita nonmuslim, tapi hal itu cukup beresiko. Banyak rumah tangga atau pasangan yang akhirnya bercerai karena dipicu oleh pertentangan pendapat karena perbedaan agama. Belum lagi menyangkut pola dan pilihan pendidikan agama buat anak-anaknya nanti. Lagi pula, apakah kalian khususnya yang cowok bisa menjamin dapat membimbing istri kalian sesuai agama Islam? Daripada bermasalah, kan lebih baik kalian pilih saja perempuan muslim; kan masih banyak.

Selanjutnya guru menunjukkan beberapa contoh pernikahan beda agama yang dilakukan beberapa tokoh yang berakhir dengan masalah. Bahkan ia memberikan contoh 'ekstrim' yakni pernikahan beda agama yang dilakukan seorang mantan pejabat tinggi negara. Guru mengakui bahwa diskusi seputar pernikahan beda agama memang selalu menarik perhatian siswa. Isu pernikahan beda agama secara tak langsung bersinggungan dengan masalah pluralisme agama. Selain muncul dalam pembahasan tentang toleransi beragama maupun topik tentang kerukunan seperti dikemukakan di atas, pertanyaan siswa tentang isu pluralisme agama memang biasanya muncul dalam pokok bahasan tentang hukum perkawinan ini. Topik bahasan ini terdapat dalam aspek Fiqih yang membahas tentang hukum keluarga menurut hukum Islam yang diajarkan pada semester ganjil. Secara khusus topik ini memang sensitif karena secara langsung membahas tentang persamaan keyakinan sebagai salah satu syarat sahnya perkawinan. ${ }^{1}$ Sebagai remaja, isu tersebut cukup antusias direspon oleh siswa. Untuk mempertegas status larangan menikah dengan nonmuslim, guru mengutip beberapa ayat yang melarang perkawinan tersebut. Kendati demikian, beberapa pertanyaan kritis selalu muncul dari peserta. Misalnya, mengapa pernikahan beda agama dilarang sementara di Jawa justeru diperbolehkan? Menghadapi pertanyaan seperti ini, guru menjawab dengan jawaban kunci:

Sekarang apakah kamu hendak mengikuti yang dilakukan di Jawa atau Al-Quran dan Hadis. Kalau kamu berislam yang benar, ikutilah petunjuk Al-Quran dan Hadis agar hidupmu bahagia dan selamat dunia akhirat.

Menurut guru, jawaban tegas tersebut harus disampaikan karena isu pernikahan campur tergolong sensitif dalam kultur masyarakat Dompu. Dengan jawaban seperti itu, dirinya berharap siswanya tidak menjalin hubungan asmara apalagi menikah dengan nonmuslim karena hal itu dilarang oleh Islam.

\section{B. Pembahasan}

Dari penjelasan guru di atas terdapat dua hal penting yang perlu dicatat. Pertama, pelaksanaan praktik pembelajaran tidak dapat sepenuhnya melepaskan diri dari tuntutan lingkungan masyarakatnya. Dalam konteks pembelajaran PAI, sikap dan penjelasan guru tentang masalah pluralisme agama seperti isu pernikahan campur, status hukum sembelihan nonmuslim, dan menghadiri acara ritual agama lain, mencerminkan pandangan-dunia (world-view) yang hidup dalam masyarakat tertentu. Dalam hal ini---berbeda dengan kultur Jawa---perbedaan agama dalam kultur masyarakat Dompu memang dipandang sebagai hal mendasar. Oleh karena itu, jawabanjawaban tegas dari guru PAI di atas terhadap isu pernikahan beda agama hakikatnya merefleksikan kenyataan-kenyataan kultural dan sosial yang hidup dalam masyarakat. Namun demikian, munculnya beberapa pertanyaan kritis seperti diajukan siswa di atas juga menunjukkan mulai adanya pergeseran pandangan terhadap pernikahan beda agama. Munculnya kesadaran baru yang mulai mempersoalkan kembali status pernikahan beda agama, boleh jadi, merupakan implikasi langsung dari globalisasi informasi yang dialami siswa. Kenyataan-kenyataan yang pernah dilihat atau dialami baik di lingkungan sosialnya maupun pengaruh media menyebabkan siswa memiliki perubahan orientasi atau cara pandang terhadap isu keagamaan seperti pernikahan beda agama. Dalam konteks pembelajaran PAI, perubahan semacam ini bukan tidak mungkin juga turut memengaruhi perspektif mereka terhadap masalah pluralisme agama.

\footnotetext{
${ }^{1}$ Menurut Pasal 22 UU No 1 Tahun 1974 tentang Perkawinan bahwa perkawinan dianggap sah apabila (1) dilakukan menurut hukum masing-masing agama dan kepercayaannya, dan (2) dicatat menurut peraturan perundang-undangan yang berlaku.
} 
Kedua, sesuai dengan coraknya PAI---bahkan semua jenis pendidikan agama umumnya---bersifat 'memihak'. Kendatipun di satu sisi orientasi pembelajaran PAI bersifat fungsional bagi kehidupan sosial, termasuk dalam menghadapi realitas kemajemukan beragama ${ }^{2}$ namun dalam praktiknya pembelajaran PAI haruslah bersifat "doktrinal, memihak, dan tidak netral" (Nasih dan Nur Kholidah, 2009: 15). Ditilik dari indikator ini tampak bahwa secara implisit orientasi pembelajaran PAI memang lebih diarahkan ke "dalam" yakni memperteguh keyakinan dan klaim kebenaran terhadap agama sendiri serta untuk peningkatan pengetahuan dan keterampilan dalam melaksanakan praktik atau ritual agama. Sebagai sebuah doktrin keagamaan maka corak pendidikan agama yang 'memihak' tersebut merupakan hal lumrah dalam setiap agama. Elaborasi maupun ilustrasi tentang toleransi beragama seperti di atas, harus diakui, masih normatif dan kering. Di sini tampak guru belum mampu mengembangkan dan memperluas penjelasan dan contoh toleransi secara lebih komprehensif. Apa yang dikemukakan guru belum keluar dari pakem formal sebagaimana yang terdapat dalam buku-buku teks PAI. Sebagai agen pembelajaran, guru menempatkan dirinya sekedar operator kurikulum dan buku teks PAI.

Pengertian maupun ilustrasi toleransi yang normatif seperti di atas, harus diakui, memang tidak mampu melahirkan kerukunan beragama yang sebenarnya. Seperti diakui banyak kalangan bahwa masalah kerukunan agama masih miskin wacana karena kerukunan hanya berhenti pada pemahaman yang verbalistik tentang banyaknya agama, tanpa didasari oleh kerangka teologi yang jelas bahwa pada masing-masing agama yang secara formal berbeda, pada dasarnya disatukan oleh komitmen spiritual dan moral yang sama. Akibatnya, kerukunan terkesan abstrak, karena sementara secara verbal mengakui perbedaan, tapi masing-masing hati pemeluk agama menyimpan benih-benih pertentangan (Fadjar dan Arifin, 2001: 8). Masalah kemiskinan wacana seperti ini tak terkecuali juga berlangsung dalam praktik pendidikan agama. Sementara di sisi lain, menggunakan kerangka Arifin (dalam Syahroni AJ, 2003), integrasi dalam pluralitas keberagamaan ditentukan oleh unsur tokoh di samping faktor pemahaman dan kebudayaan yang sama yang terdapat dalam suatu komunitas tertentu. Dalam konteks pembelajaran PAI maka guru, tak diragukan lagi, dapat menjadi figur yang turut memengaruhi sikap dan pandangan siswa dalam memahami maupun merespon persoalan pluralisme agama.

Hingga kini sekolah masih diyakini sebagai salah satu elemen penting yang memengaruhi corak kehidupan masyarakat. Sebagai lembaga pendidikan resmi, sekolah memainkan peranan signifikan dalam melakukan rekayasa formal terhadap cara berpikir peserta didik dan anggota masyarakat. Hal itu karena institusi sekolah dipandang memiliki beberapa kekuatan. Menurut Harold G. Shane (dalam Muqaddimah Jurnal Ulumuddin, 2000: 1) pendidikan memiliki empat potensi terhadap kehidupan masa depan. Pertama, pendidikan menyediakan wahana untuk implementasi nilai-nilai pada masyarakat yang berubah. Kedua, pendidikan dapat dipakai untuk menanggulangi masalahmasalah sosial tertentu. Ketiga, pendidikan meningkatkan kemampuan untuk menerima dan mengimplementasikan alternatif-alternatif baru. Keempat, pendidikan merupakan cara terbaik untuk membimbing perkembangan manusia hingga memberikan kontribusi pada kebudayaan masa depan.

Dalam konteks pluralitas keagamaan, ini berarti bahwa sekolah bertanggungjawab menyiapkan peserta didik untuk menjawab tantangan masa depan, termasuk hidup dalam realitas kemajemukan beragama. Hal itu karena internalisasi nilai-nilai pendidikan di sekolah akan memengaruhi dan ikut membentuk persepsi, sikap dan perilaku seseorang dalam merespon realitas kemajemukan dalam lingkungan sosialnya. Menurut Arifin (dalam Syahroni AJ, 2003: 100), ada tiga faktor utama yang mendukung integrasi dalam pluralitas keberagamaan. Pertama, pemahaman agama, yang menekankan pada pemaknaan secara eksternal dan internal agama yang dipeluknya maupun agama yang dipeluk orang lain. Pemaknaan internal menunjukkan bahwa masyarakat tetap meyakini kebenaran agama yang dipeluknya. Sedangkan eksternal menunjukkan

\footnotetext{
${ }^{2}$ Menurut PUSKUR Depdiknas tujuan PAI adalah untuk menumbuhkan dan meningkatkan keimanan peserta didik melalui pemberian dan pemupukan pengetahuan, penghayatan, pengamalan serta pengalaman peserta didik tentang agama Islam sehingga menjadi manusia muslim yang terus berkembang dalam hal keimanan, ketakwaannya kepada Allah SWT serta berakhlak mulia dalam kehidupan pribadi, bermasyarakat, berbangsa dan bernegara. (Nasih dan Nur Kholidah, 2009: 7). Adapun indikator dan karakteristik pembelajaran PAI adalah (1) mempunyai dua sisi kandungan yakni sisi keyakinan dan sisi pengetahuan (2) bersifat doktrinal, memihak, dan tidak netral (3) pembentukan akhlak yang menekankan pada pembentukan hati nurani dan penanaman sifat-sifat ilahiyah yang jelas dan pasti (4) bersifat fungsional (5) diarahkan untuk menyempurnakan bekal keagamaan peserta didik dan (6) diberikan secara komprehensif (Nasih dan Nur Kholidah, 2009: 15).
} 
bahwa dalam agama lain juga ada kebenaran yang seharusnya juga perlu dihormati. Kedua, rasa memiliki kebudayaan yang sama (sense of common culture). Ketiga, tokoh agama dan tokoh masyarakat yang akomodatif yang bisa menyelesaikan konflik antarkelompok agama.

Adanya pemahaman agama sebagai salah satu prasyarat intergratif dalam pluralitas agama sebagaimana dikemukakan di atas, tentu menempatkan lembaga pendidikan sebagai salah satu agen sosial cukup penting. Besarnya pengaruh lembaga pendidikan tersebut makin penting mengingat kenyataan bahwa 'agama' merupakan salah satu faktor 'pemisah' yang membuat seseorang merasa 'berbeda' dengan orang atau kelompok lain. Menurut Susanto (dalam Fadjar dan Arifin, 2001: 6) dalam interaksi sosial terdapat dua jenis jarak sosial yaitu jarak sosial objektif dan subjektif. Karsidi (dalam Fadjar dan Arifin, 2001: 6) menjelaskan bahwa jarak sosial objektif meliputi jarak yang disebabkan oleh keadaan geografis dengan kesukaran transportasi, agama, etnis dan status social ekonomi. Sedangkan jarak sosial subjektif adalah perasaan dan pikiran seseorang terhadap orang lain yang hendak (tak ingin) diajak berkomunikasi. Sebagai faktor subjektif, perasaan dan pikiran seseorang terhadap orang lain banyak berhubungan dengan kesan (impresi), yaitu hasil persepsi seseorang terhadap pihak lain yang diajak berkomunikasi.

Berdasarkan kategori di atas, tampak bahwa ternyata (perbedaan) agama dapat menjadi sumber munculnya berbagai prasangka dalam hubungan sosial. Oleh karena itu, sebagai salah satu agen sosial maka pendidikan akan ikut memengaruhi konfigurasi dan tatanan sosial (social order) di masyarakat. Secara khusus, pentingnya peran pendidikan tersebut tergantung peran guru.

\section{SIMPULAN DAN SARAN}

\section{A. Simpulan}

Dari uraian tersebut di atas dapat ditarik kesimpulan bahwa praktik pembelajaran PAI tentang pluralisme agama di SMAN 1 Dompu masih sangat kuat dipengaruhi oleh semangat klaim kebenaran (truth claim) yakni memandang dan memperlakukan agama selain Islam secara stigmatik. Selain hanya melahirkan toleransi semu, dalam jangka panjang klaim seperti itu juga menyebabkan sulit mendorong lahirnya dialog agama yang terbuka dan jujur. Demikian pula, kendati corak pembelajaran PAI mencakup aspek 'pengetahuan' dan 'keyakinan' tapi dalam praktiknya aspek keyakinan lebih menonjol. Di samping itu, dalam praktik pembelajaran guru hanya menempatkan diri sekadar operator dari apa yang terdapat dalam buku-buku teks sehingga siswa sulit mendapatkan pandangan maupun pemahaman lain sebagai pembanding (second opinion) tentang materi pembelajaran pluralisme agama.

\section{B. Saran}

Untuk mewujudkan kehidupan beragama yang harmonis dan sejati maka relasi umat beragama tidak cukup hanya mengandalkan sikap saling menghormati tapi yang lebih penting adalah saling memahami. Sikap terakhir ini hanya bisa tercapai jika tiap umat beragama bersikap terbuka, jujur dan saling belajar serta memahami agama satu dengan lainnya. Dalam konteks ini, guru sebagai agen pembelajaran memiliki peran penting dalam menumbuhkan nilai-nilai kemajemukan tersebut. Para pemangku kepentingan memiliik tanggung jawab untuk membantu dan memberdayakan guru-guru PAI maupun guru agama umumnya dalam memberdayakan tugas-tugas profesionalnya sebagai guru baik berupa pelatihan, studi banding, kegiatan ilmiah maupun bantuan lainnya.

\section{DAFTAR RUJUKAN}

AJ, Syahroni. 2003. "Pluralisme Keberagamaan: Wawasan Subyek Dakwah". Dalam Jurnal Wacana No. 1, Vol. 3, November.

Cholil, Suhadi dkk. 2010. Laporan Tahunan Kehidupan Beragama di Indonesia 2009. Yogyakarta: CRCS-UGM.

Fadjar, A. Malik dan Arifin, Syamsul. 2001. “Muhammadiyah dan Pluralisme Agama”. Dalam Jurnal Ulumuddin No 1, Thn IV, Juli.

Jalal, F\&Musthafa, B. 2001. Education Reform in The Context of Regional Autonomy: The Case of Indonesia. Jakarta: Ministry of National Education-National Development Planning Agency, The Republic of Indonesia. 
Muqaddimah Jurnal Ulumuddin No. 4 Thn 3, Juni 2000.

Nasih, Ahmad Munjin dan Nur Kholidah, Lilik. 2009. Metode dan Teknik Pembelajaran Pendidikan Agama Islam. Bandung: Refika Aditama.

Nasr, Seyyed Hossein. 1993. Islam dan Filsafat Perenial. Terj. Rahmani Astuti. Bandung: Mizan.

Nasution, Muslim. 2000. "Pembentukan Akhlak Mulia bagi Siswa SMU”. Dalam Jurnal Pendais Vol.1 No. 3, September.

Peraturan Menteri Pendidikan Nasional No 22 Tahun 2006 tentang Standar Isi Mata Pelajaran PAI untuk Sekolah Menengah Atas.

Siti Khairiah. 2011. Rencana Pelaksanaan Pembelajaran Mata Pelajaran Pendidikan Agama Islam SMAN 1 Dompu.

Schoun, Frithjof. 1994. Mencari Titik-Temu Agama-agama. Terj. Saafroedin Bahar. Jakarta: Pustaka Firdaus.

Tilaar, HAR \& Nugroho, R. 2008. Kebijakan Pendidikan. Yogyakarta: Pustaka Pelajar.

WJS. Poerwadarminta. 1984. Kamus Umum Bahasa Indonesia. Jakarta: PN Balai Pustaka.

http://www.sacredheart.edu/pages/13027 the dialogue decalogue by leonard swidler.cfm. Diunduh tgl 23 November 2010. 